\title{
PROFILE OF HIGH SCHOOL STUDENTS REFLECTIVE THINKING IN SOLVING ALGEBRA PROBLEMS VIEWED FROM MATHEMATICAL ABILITY
}

\author{
Dyah Ayu Puspita Ardani \\ Pendidikan Matematika, Fakultas Matematika dan Ilmu Pengetahuan Alam, Universitas Negeri Surabaya \\ e-mail: dyah.17030174016@mhs.unesa.ac.id \\ Pradnyo Wijayanti \\ Pendidikan Matematika, Fakultas Matematika dan Ilmu Pengetahuan Alam, Universitas Negeri Surabaya \\ e-mail: pradnyowijayanti@unesa.ac.id
}

\begin{abstract}
This study aims to describe students' reflective thinking in solving algebraic problems with different mathematical abilities. This study used reflective thinking components by Surbeck, Han, and Moyer, including reacting, elaborating, and contemplating. This study was descriptive qualitative research that used a qualitative approach. The instruments in this study were mathematical ability tests, mathematical problemsolving tests, and interview guidelines. This study was conducted by selecting three subjects from 31 students of SMAN 1 Pacet with female gender who have high, medium, and low mathematical abilities. This study's results were at the reacting stage; the three students analyzed what was known and asked according to the information provided, analyzed the relationship between what was known and asked, and reasons. At the elaborating stage, the three students were able to analyze the theory used. High and low-ability students have encountered similar questions. Medium ability students admitted that they had never met similar questions but examined the differences. High and medium-ability students explain the results obtained in detail at the contemplating stage, check their results, and make conclusions. Low ability students only explain part of the solution because they cannot find the solution. They try to correct their mistakes but give up, so they do not make conclusions. For low-ability students, the teacher can provide practice questions that trigger reflective thinking to solve math problems correctly and improve their weaknesses.
\end{abstract}

Keywords: reflective thinking, mathematics problems, high school algebra, mathematical ability.

\section{INTRODUCTION}

Mathematics, the queen of science, is the fundamental science for other scientific branches. Mathematical competence focuses on mastering concepts, algorithms, and solving everyday life problems (Fatmahanik, 2016). Permendikbud No. 21 of 2016 stated that "students are expected to show the ability to think logically, critically, analytically, carefully and thoroughly, be responsible, responsive, have reflective thinking, and do not give up easily in solving problems". Individual thinking ability is a parameter to achieve mathematics learning goals, especially higher-order thinking skills, such as critical, creative, logical, analytical, and reflective thinking skills. Thinking can be interpreted as a human activity, starting from receiving, processing, summarizing, and recalling the information in his memory.

According to Suharna (2018), reflective thinking is a way of thinking to solve problems in a sustainable, persistent, and objective manner. Reflective thinking is an individual's psychological activity in analyzing, evaluating, and considering everything logically and weighing the consequences of his decisions. The purpose of reflective thinking is to achieve learning activities and obtain new learning methods that can affect the learning process. According to Skemp's (1982) opinion, "reflective thinking can be described as thinking that responds to problems by using information or data from within that can explain what has been done, corrects errors found in solving problems, and communicates ideas with symbols." The researcher used the reflective thinking component proposed by Surbeck, Han, and Moyer because it relates more to problem-solving in mathematics. Surbeck et al. (1991) stated three components in reflective thinking: reacting, elaborating, and contemplating. In the reacting stage, the student activities are commenting on learning experiences, such as responding with attention to problems. Students compare reactions and other learning experiences in the elaborating stage, such as referring to the theory they already have. At the contemplating stage, student activities are focusing attention on personal understanding of the problem or difficulty.

The teacher can recognize a student's reflective thinking ability through activities that trigger students to show reflective thinking skills, such as solving mathematics problems. Students want to find experience by using their 
knowledge and skills that already have to be applied in solving problems so that students are more analytical in making decisions. A person can describe a matter according to its components so that they can get the relationship. According to Santrock (2011), students with a reflective style tend to spend more time responding and reflecting on the accuracy of answers, being careful, and giving correct answers. Based on the field's reality, the mastery of mathematics material for students at the primary education level and students at the secondary level is still classified as low. Based on Puspendik's (2019) information, the low mastery of mathematics material seen from the average national exam results for high school mathematics in Indonesia in 2019 only reached 35.26. In overcoming some mathematics learning problems, students are taught and trained to solve a problem using their higherorder thinking skills, namely reflective thinking.

According to Booker (2009), algebra acts as a tool for solving math problems related to everyday life. In developing mathematical problems, the material that is considered necessary is algebra (Visitasari \& Siswono, 2013). One of the materials related to algebraic problems is the material of three-variable linear equations. Cardo A.P. et al. (2020) stated that students have difficulty completing applications in everyday life about three-variable linear equations. Due to the lack of conscientiousness, students' accuracy, and changing the story problem into a mathematical model. According to research by Azis et al. (2018), the difficulties experienced by students in solving three variable linear equation system problems include (1) misconceptions which contain determining formulas, using formulas, and writing formulas to answer the given issues; (2) Errors in regular procedures regarding troubleshooting steps.

Putri \& Mampouw (2018) state that everyone has a different way of solving mathematics problems because everyone has different thinking abilities. Differences in mathematical abilities are indicated to affect students' reflective thinking in solving problems. Based on facts in the field, in solving math problems, besides focusing on reflective thinking skills, it is also necessary to pay attention to students' mathematical abilities. Nurman (2008) states that each student's mathematical ability will affect the problem process carried out. The achievement of the ability to think reflectively needed to solve mathematical problems utilizes students' mathematical abilities, while to receive and process information, each student has different abilities. This means that differences in students' mathematical abilities which affect their reflective thinking skills mean solving a mathematical problem. In line with Jannah \& Rahaju (2018) research, there is a significant difference in students' reflective thinking in solving problems based on mathematical ability. Students with high mathematical abilities can do all components of reflective thinking. Students with the medium mathematical ability only fulfill part of the components in reflective thinking. Students who have low mathematical abilities are only able to do elaborating.

Many researchers research reflective thinking, such as Jannah \& Rahaju (2018) research, reflective thinking in problem-solving in terms of students' mathematical abilities with male junior high school students on the material of two-variable linear equation systems. Then, Salido \& Dasari (2019) research the analysis of reflective thinking skills based on high school students' mathematical abilities on the topic of geometry. However, there are still relatively few studies that discuss the profile of reflective thinking in solving algebraic problems with female high school students as subjects.

From the description above, this study aimed to describe students' reflective thinking profile in solving algebraic problems with the categories of high, medium, and low mathematical abilities.

\section{METHOD}

This research uses a qualitative approach. This type of research is a qualitative descriptive study. Qualitative research is a research stage to obtain descriptive data in speech, writing, and behavior on the object or subject being observed (Siswono, 2019). This research's data sources were 31 students of class X MIPA 1 SMAN 1 Pacet Mojokerto in the 2020/2021 academic year. The research was carried out in several stages, including (1) preparation, namely the preparation and validation of research instruments by the lecturer consisting of a mathematical ability test (ABT), a mathematical problem-solving test (MPST) and interview guidelines, (2) subject selection, (3) data collection, and (4) data analysis.

At the subject selection stage, students are given an online mathematical ability test (ABT) which consists of 10 essay questions with a time of 90 minutes. The mathematical ability test was conducted in a heterogeneous class and had received material on the system of threevariable linear equations. The mathematical ability test was used to select subjects with various categories of mathematical abilities. This mathematical ability category is based on Permendikbud No. 23 of 2016 concerning KKM (Minimum Completeness Criteria), determined by the academic unit. The mathematical ability category based on the school's KKM score with a value of 75 can be seen in Table 1 below.

Table 1. Mathematics Ability Category

\begin{tabular}{|c|c|}
\hline Score & Category \\
\hline $83<\mathrm{x} \leq 100$ & High \\
\hline
\end{tabular}




\begin{tabular}{|c|c|}
\hline $75 \leq \mathrm{x} \leq 83$ & Medium \\
\hline $\mathrm{x}<75$ & Low \\
\hline
\end{tabular}

After a mathematical ability test, three students were selected with different abilities: one student with high ability, one student with medium ability, and one student with low ability. Putri \& Mampouw (2018) state that one of the phases of reflective thinking was a difference between male and female students, where female students did not consider their experiences to solve a problem. Therefore, the subject selection also considers the same gender (female) to avoid data differences caused by sex differences.

At the data collection stage, the three selected students were given a mathematics problem-solving test (MPST) consisting of a three-variable linear equation system problem. Research subjects were given 60 minutes to solve the problem. The following is a mathematical problemsolving test that is used to determine the student's reflective thinking profile. "An art show in the city center that will be held at the end of the year sells three types of tickets, namely tickets for adults (21 years and over) at 80.000 IDR. For teenagers (ages 13 to 20 years), tickets are sold at 50.000 IDR, while for children (under 13 years), a ticket fee is charged at 20.000 IDR. Currently, 170 tickets have been sold, with the total revenue from ticket sales of 9.400.000 IDR. If the tickets sold are for teenagers tickets, twice as many adult tickets have already been sold. Count the number of tickets sold for each type of ticket! ". After the subject worked on the MPST, the researcher interviewed the subject to determine the data's suitability between the MPST written test results and the oral test during the interview. The results of MPST and interviews were analyzed based on the indicators of reflective thinking in the following table.

Table 2. Indicators of Reflective Thinking Ability in Solving Algebra Problems

\begin{tabular}{|c|c|}
\hline $\begin{array}{c}\text { Reflective } \\
\text { Thinking } \\
\text { Components }\end{array}$ & Indicators \\
\hline Reacting & $\begin{array}{l}\text { a. Analyze known things from } \\
\text { mathematics problems } \\
\text { b. Analyze what is asked in } \\
\text { mathematics problems } \\
\text { c. Analyze the relationship } \\
\text { between the questioned and } \\
\text { the known } \\
\text { d. Checking what is known is } \\
\text { sufficient to answer what is } \\
\text { asked }\end{array}$ \\
\hline Elaborating & $\begin{array}{l}\text { a. Analyze the theory used in } \\
\text { solving mathematics } \\
\text { problems }\end{array}$ \\
\hline
\end{tabular}

\begin{tabular}{|c|c|}
\hline & $\begin{array}{l}\text { b. Remembering having faced } \\
\text { a similar problem before } \\
\text { c. Analyze the relationship } \\
\text { between problems that have } \\
\text { been faced with current } \\
\text { problems }\end{array}$ \\
\hline Contemplating & $\begin{array}{l}\text { a. Solve mathematics problems } \\
\text { coherently } \\
\text { b. Correct the completion that } \\
\text { has been made } \\
\text { c. Repair if something goes } \\
\text { wrong } \\
\text { d. Make conclusions correctly } \\
\text { regarding existing } \\
\text { mathematics problems }\end{array}$ \\
\hline
\end{tabular}

At the data analysis stage, the analysis technique used in this research is according to Sugiyono (2014) analysis steps which include data reduction, which means summarizing, classifying, and focusing on essential things. Presenting data is a systematic preparation of information and drawing meaningful conclusions. The conclusion is the process of taking essence in the form of a clear and concise sentence statement.

\section{RESULT AND DISCUSSION Research Result}

Research data collection was carried out in class X MIPA 1 SMAN 1 Pacet Mojokerto academic year 2020/2021 on January 14-18, 2021. The research subjects were selected based on the provision of ABT to all students of class $\mathrm{X}$ MIPA 1. Based on the results of ABT and classification of mathematical abilities, The test scores that have been carried out by referring to Table 1 can be seen in their mathematical abilities. There are only one high category student, one medium category student, and 29 low category students. For the selection of low category students based on the lowest mathematical ability test scores and being female. Data from the mathematical ability test results were determined by several students based on discussions with the mathematics teacher. The following shows the selected students who are the research subjects.

Table 3. Research Subjects

\begin{tabular}{|c|c|c|c|}
\hline $\begin{array}{c}\text { Initial } \\
\text { Student }\end{array}$ & Score ABT & Category & Subject \\
\hline KFZ & 90 & High & MT \\
\hline SMS & 78 & Medium & MS \\
\hline EO & 48 & Low & MR \\
\hline
\end{tabular}

Furthermore, three research subjects finished the MPST, which was used to determine high school students' reflective thinking profile in solving algebraic problems. 
The three research subjects were interviewed to obtain full details.

Table 4. Interview Result Code

\begin{tabular}{|l|l|}
\hline Code & \multicolumn{1}{|c|}{ Information } \\
\hline Re & Re is research \\
\hline Mxy & $\begin{array}{l}\text { Mxy means the information conveyed } \\
\text { by a subject with mathematical ability } x, \\
\text { order y. } \\
\text { For example MT12 is information } \\
\text { conveyed by a subject with high } \\
\text { mathematical ability in the 12th order. }\end{array}$ \\
\hline
\end{tabular}

\section{Results and data analysis on the subject of high mathematical ability (MT)}

The following are the results of the MT subject written test in solving MPST questions. The code presented has the meaning $\mathrm{H}=$ written test result, $\mathrm{ST}=$ high category subject, and the numbers indicate the order.

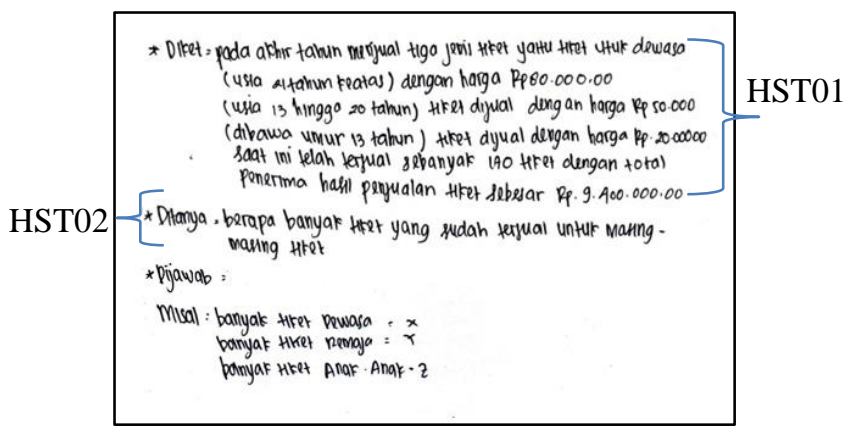

Figure 1. MTR Written Test Results

Based on the results of the MTR written test above. MT can analyze known things (HST01) by writing down essential information in full. MT explores the things that are asked (HST02) on these mathematics problems. MT can retell it in her language according to the results of the following interview.

Re $\quad$ "Can you explain in your own words
wT01 : "Frat is meant by this problem?"
performance with adult tickets sold for
80.000 IDR, then for teenagers tickets
are sold at 50.000 IDR, while for
children themselves, tickets are charged
20.000 IDR. Currently, 170 tickets are
sold for a total of 9.400.000 IDR.
Tickets sold for teenagers are twice the
adult tickets, counting the number of
tickets sold for each ticket type."
"What important information did you
use to find this solution?"

MT02 : "Ticket price information, which sold 170 tickets for a total of nine million and four hundred teen tickets sold twice as adult tickets." (HST01)

$\operatorname{Re} \quad:$ "What does this question ask?"

MT03 : "Yes, a lot of each ticket was sold." (HST02)

Re : "Ok, then what is the relationship between what is known and what is asked?"

MT04 : "Yes, Miss, there is a ticket price for each, then there is a total that is obtained, then look for the number of each ticket."

Re : "Is the known information sufficient to answer this problem and why?"

MT05 : "Enough because we know that we can make three equations, Miss."

Based on the interview results above, MT stated a relationship between what was known (MT02) and what was asked (MT03). MT says that the information learned is sufficient to answer the problem along with the reasons for it (MT04). MT can show all components of reflective thinking.

In the reflective thinking component, namely elaborating, MT uses theory and methods appropriately. MT has encountered a similar problem by analyzing the similarities and differences between recent questions and questions that have been faced before. The following is a conversation during the interview with MT regarding the elaborating stage.

\begin{tabular}{|c|c|c|}
\hline $\operatorname{Re}$ & : & $\begin{array}{l}\text { "From this problem, what theory do you } \\
\text { think you use to solve this problem?" }\end{array}$ \\
\hline MT06 & . & $\begin{array}{l}\text { "System of three-variable linear } \\
\text { equations." }\end{array}$ \\
\hline $\operatorname{Re}$ & : & $\begin{array}{l}\text { "Have you ever come across a question } \\
\text { like this?" }\end{array}$ \\
\hline МT07 & : & "Yes, Miss." \\
\hline $\mathrm{Re}$ & . & $\begin{array}{l}\text { "What makes this problem different } \\
\text { from the problems you've worked on?" }\end{array}$ \\
\hline МТ08 & . & $\begin{array}{l}\text { "If my teacher's question is a } \\
\text { straightforward equation, there are three } \\
\text { equations } x+y+z=\ldots \text { then asked to } \\
\text { find the values for } x, y, z \text {. Same three } \\
\text { pencils plus one book plus two pens } \\
\text { equals } 30.000 \text { IDR." }\end{array}$ \\
\hline $\operatorname{Re}$ & & $\begin{array}{l}\text { "Good. What method did you use to } \\
\text { solve this problem and why?" }\end{array}$ \\
\hline 109 & & $\begin{array}{l}\text { "Mixed method Miss. It's an easy } \\
\text { method." }\end{array}$ \\
\hline
\end{tabular}




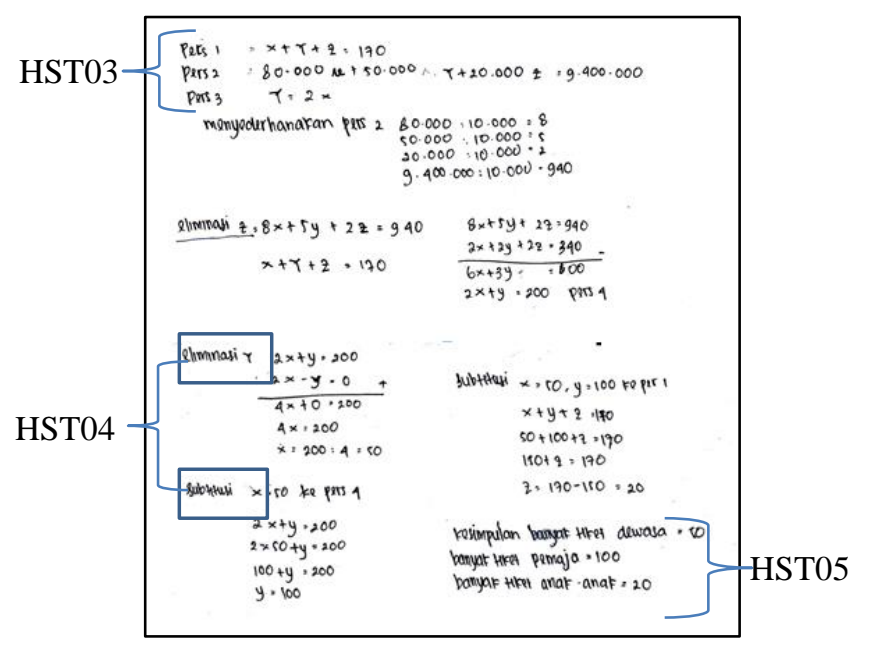

Figure 2. MTE Written Test Results

Based on the MTE written test results above, at the contemplating stage, MT can solve algebraic problems coherently with the substitution and elimination method (HST04). MT also explains the initial process by taking the variables $\mathrm{x}, \mathrm{y}, \mathrm{z}$, then three variable linear equations. MT simplifies one of the equations and eliminates the $\mathrm{z}$ variable. We get equation 4. MT also eliminates the $\mathrm{y}$ variable in equations $3 \& 4$ to get the $x$ value, then substitutes the $\mathrm{x}$ value into equation 4 to get $\mathrm{y}$ value. MT explains the written test results to the end in Figure 2, which contains each variable's value and conclusions.. The results of the interview with MT are discussed to learn more about the contemplating stage.

\begin{tabular}{|c|c|c|}
\hline $\operatorname{Re}$ & $:$ & $\begin{array}{l}\text { "Try to explain the steps in solving this } \\
\text { problem?" }\end{array}$ \\
\hline MT10 & : & $\begin{array}{l}\text { "First, it makes, for example, } \mathrm{x} \text { equal to } \\
\text { many adult tickets, } \mathrm{y} \text { equal to many teen } \\
\text { tickets, } \mathrm{z} \text { equal to many child tickets. } \\
\text { Then make these three equations so that } \\
\text { my equation } 2 \text { is easy for } 10 \text { thousand. } \\
\text { Then eliminating } \mathrm{z} \text { from equations } 1 \text { and } \\
2 \text { gives } 2 \mathrm{x}+\mathrm{y}=200 \text {. Then canceling } \\
\text { this y variable gets } \mathrm{x}=50 \text {. I substituted } \\
\mathrm{x}=50 \text { into the equation } 2 \mathrm{x}+\mathrm{y}=200 \text { so } \\
\mathrm{y}=100 \text {. Then I substituted } \mathrm{x}=50 \text { and y } \\
=100 \text { into equation } 1 \text {, getting } \mathrm{z}=20 \text {." }\end{array}$ \\
\hline $\operatorname{Re}$ & : & $\begin{array}{l}\text { "Good. Did you double-check the steps } \\
\text { for this solution?" }\end{array}$ \\
\hline MT11 & : & "Yes, Miss." \\
\hline $\operatorname{Re}$ & : & "How did you check?" \\
\hline MT12 & : & $\begin{array}{l}\text { "That's Miss. I put the values of } \mathrm{x}, \mathrm{y}, \mathrm{z} \\
\text { into each equation (HST03). If it is true, } \\
\text { it means the values of } \mathrm{x}, \mathrm{y}, \mathrm{z} \text { are } \\
\text { correct." }\end{array}$ \\
\hline $\operatorname{Re}$ & $\cdot$ & "Are you sure your answer is correct?" \\
\hline MT13 & & "Sure, Miss" \\
\hline
\end{tabular}

$\operatorname{Re}$

MT14 : "From the results I got, there were 50 tickets sold for adults. Many teenage tickets were sold, with 100 tickets. Many children's tickets sold 20 tickets." (HST05)

Based on the above interview (MT12), MT has rechecked the results obtained by substituting them for each equation. MT believes that the answer it gets is correct. MT can make conclusions orally or in writing (HST05). Based on the description above, MT shows all reflective thinking stages, starting from reacting, elaborating, and contemplating well.

\section{Results and data analysis on the subject of medium mathematical ability (MS)}

The following are the results of the MS subject written test in solving MPST questions. The code presented has the meaning $\mathrm{H}=$ written test result, $\mathrm{SS}=$ medium category subject, and the numbers indicate the order.

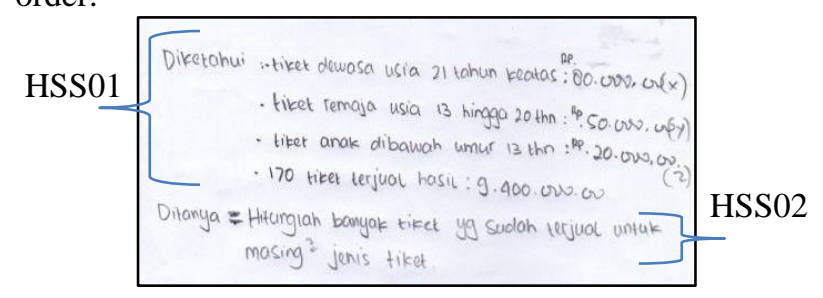

Figure 3. The results of the MSR written test

Based on the results of the MSR written test. MS can analyze known things (HSS01) by writing down the important information it gets. MS can analyze the things that are asked (HSS02). The following is an excerpt from an interview with MS to explore more details.

Re : "Can you explain in your own words what is meant by this problem?"

MS01 : "Asked to count the number of each ticket. Recently, 170 tickets were sold, totaling 9.400.000 IDR."

Re : "What important information did you use to find this solution?"

MS02 : "For adult tickets, 80.000 IDR. For teenagers, 50.000 IDR. And for children 20.000 IDR. There were 170 tickets sold totaling 9.400.000 IDR and teen ticket twice adult ticket." (HSS01)

$\operatorname{Re} \quad$ : "What is asked in this question?"

MS03 : "Count the number of tickets each sold." (HSS02)

Re : "What is the relationship between what is known and what is asked?" 
MS04 : "The connection is that there is twice the number of teen tickets sold today. So you can find each ticket."

Re : "Is the known information sufficient to answer this problem, and why?"

MS05 : "It's relatively straightforward because I can make the equations."

Based on the interview above, MS told her in her language regarding the problems presented (MS01). MS can clearly state what is known (MS02) and asked about the issues (MS03). MS said that there is a relationship between what is known and what is asked (MS04). MS admits that what is known is sufficient to answer the problem along with the reasons (MS05). MS can show all indicators of reflective thinking stages, namely reacting.

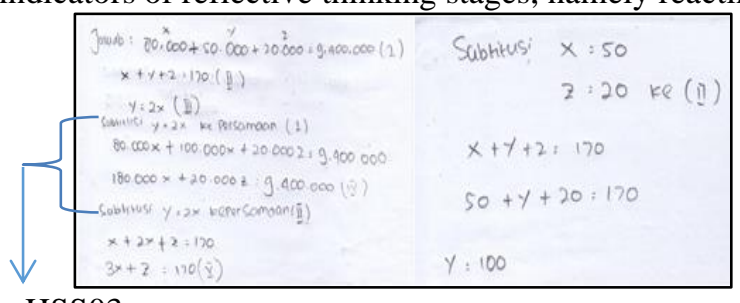

HSS03

Figure 4. MSE written test results

\begin{tabular}{|c|c|c|}
\hline $\operatorname{Re}$ & $:$ & $\begin{array}{l}\text { "What mathematical concepts do you } \\
\text { think were used to find this solution?" }\end{array}$ \\
\hline MS06 & $:$ & $\begin{array}{l}\text { "System of three-variable linear } \\
\text { equations." }\end{array}$ \\
\hline $\operatorname{Re}$ & $:$ & $\begin{array}{l}\text { "Have you ever come across a question } \\
\text { like this?" }\end{array}$ \\
\hline MS07 & $:$ & "Never before, Miss." \\
\hline $\operatorname{Re}$ & $:$ & $\begin{array}{l}\text { "In the past, what kind of questions did } \\
\text { SPLTV work on?" }\end{array}$ \\
\hline MS08 & $:$ & $\begin{array}{l}\text { "As far as I remember, there was an } \\
\text { immediate similarity. It doesn't matter a } \\
\text { story like this." }\end{array}$ \\
\hline $\operatorname{Re}$ & $:$ & $\begin{array}{l}\text { "In solving this problem, use what } \\
\text { methods and why?" }\end{array}$ \\
\hline MS09 & $:$ & $\begin{array}{l}\text { "Mixed methods miss. The reason is } \\
\text { that it is explained first and then } \\
\text { substituted and eliminated. It's an easy } \\
\text { method." (HSSO3) }\end{array}$ \\
\hline
\end{tabular}

Based on the above interview results, MS uses the concept of a three-variable linear equation system. MS admitted never encountered a similar question, but she revealed the differences between the problems she had met and the current questions (MS08). MS uses the substitution and elimination method (HSSO3) because it is considered the easiest method.

$\operatorname{Re} \quad$ : "Try to explain the steps you took to solve this problem?"
MS10 : "First known and asked. Start from creating equations $1,2,3$. Substituting $y$ $=2 \mathrm{x}$ into equation 1 is $180000 \mathrm{x}+$ $20000 z=9400000$. Substituting $y=2 x$ into equation 2 is $3 x+z=170$. Then the $z$ is removed so that you find $x=50$. Then substitute $x=50$ to $3 x+z=170$, find $z=20$. This is the last one $x=50$ and $\mathrm{z}=20$ substituted for $\mathrm{x}+\mathrm{y}+\mathrm{z}=$ 170 the result is $y=100$. It's already Miss."

Re : "Did you double-check these completion steps?"

MS11 : "No."

$\operatorname{Re} \quad$ : "Are you sure that your answer is correct and why?"

MS12 : "God willing, sure, miss. The reason is that when $y=2 x, x=50$ means $y=100$ ,and my answer is like that."

Re : ' $Z$ value $=20$. Are you sure that's true too?"

MS13 : "God willing, miss."

$\operatorname{Re} \quad$ : "What can you conclude from your results?"

MS14 : "There are 50 tickets sold for adults, 100 teenagers, 20 children, Miss."

Based on the interview above, MS can solve algebraic problems coherently with mixed methods (substitution and elimination) at the contemplating stage. MS explained the initial process of solving the problem, namely making three equations, then substituting equation 3 to equations $1 \& 2$, obtaining equations $4 \& 5$, then eliminating $\mathrm{z}$, obtaining the $\mathrm{x}$ value. MS also explained that until the end, it was by the results of the written test in Figure 8. MS did not re-check the results it got. MS believes that the answer he got is correct (MS13). MS does not make conclusions in writing but makes conclusions verbally (MS14). Based on the description above, MS shows all reflective thinking stages, starting from reacting, elaborating, and contemplating well.

\section{Results and data analysis on the subject of low mathematical ability (MR)}

The following are the results of the MR subject's written test in solving the MPST questions. The code presented has the meaning $\mathrm{H}=$ written test result, $\mathrm{SR}=$ low category subject, and the numbers indicate the order.

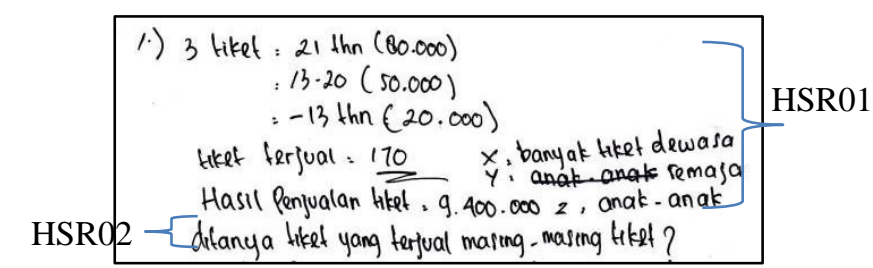


Figure 5. MRR written test

Based on the MRR written test results above, MR can analyze known things (HSR01) by writing down the age and price of tickets with brackets only, tickets sold, and the results of ticket sales. MR can analyze the thing being asked (HSR02), namely the number of tickets sold of each type according to the problem given.

\begin{tabular}{|c|c|c|}
\hline $\operatorname{Re}$ & & $\begin{array}{l}\text { "Can you explain in your own words } \\
\text { what is meant by this problem?" }\end{array}$ \\
\hline MR01 & : & $\begin{array}{l}\text { "An art show in the city center to be held } \\
\text { at the end of the year. They are selling } \\
\text { adult tickets for } 80000 \text { IDR, teenagers at } \\
50.000 \text { IDR, while for children it costs } \\
20.000 \text { IDR. Currently, } 170 \text { tickets have } \\
\text { been sold with total ticket sales revenue } \\
\text { of } 9.400 .000 \text { IDR." }\end{array}$ \\
\hline $\operatorname{Re}$ & : & $\begin{array}{l}\text { "What important information did you } \\
\text { use to find this solution?" }\end{array}$ \\
\hline MR02 & : & $\begin{array}{l}\text { "Ticket prices, Tickets sold } 170 \text { with an } \\
\text { income of } 9.400 .000 \text { IDR. And youth } \\
\text { ticket twice adult ticket." (HSR01) }\end{array}$ \\
\hline $\operatorname{Re}$ & : & "What does this question ask?" \\
\hline MR03 & : & "Each ticket sold." (HSR02) \\
\hline $\operatorname{Re}$ & & $\begin{array}{l}\text { "What is the relationship between what } \\
\text { is known and what is asked?" }\end{array}$ \\
\hline MR04 & : & $\begin{array}{l}\text { "The relationship between ticket prices } \\
\text { and tickets sold, Miss." }\end{array}$ \\
\hline $\operatorname{Re}$ & : & $\begin{array}{l}\text { "Is the known information sufficient to } \\
\text { address this issue and why?" }\end{array}$ \\
\hline MR05 & & "Yes, Because.... I don't know, Miss." \\
\hline
\end{tabular}

Based on the interview above, MR told in her language regarding the problems presented. MR can state things that are known (MR02) and asked clearly (MR03). MR says that there is a relationship between what is known and what is asked. MR admits that what is known is sufficient to answer the problem, but a reason does not accompany it (MR05).

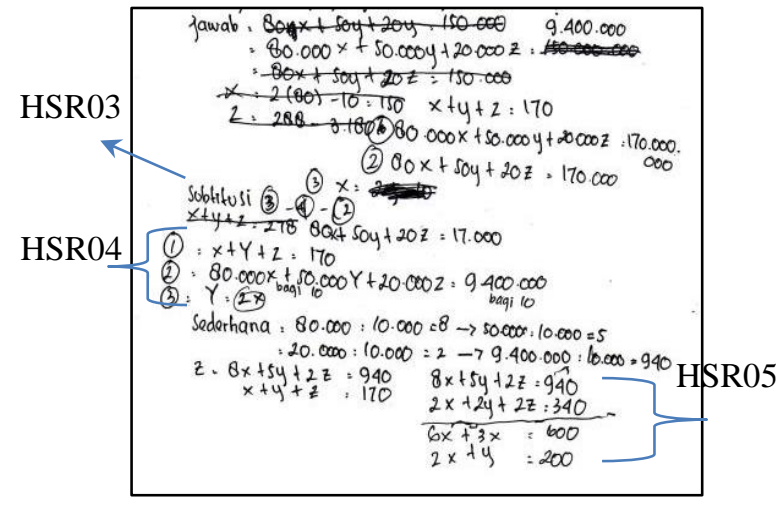

Figure 6. MRE writing test
$\operatorname{Re} \quad$ : "What mathematical concepts do you think you used to find the solution to this solution?"

MR06 : "It looks like the variable equation."

$\operatorname{Re} \quad$ : "Have you ever come across a question like this?"

MR07 : "Yes, Miss."

$\operatorname{Re} \quad$ :What are the similarities and differences between this problem and the problems you have encountered?"

MR08 : "The equation is the number 170."

$\operatorname{Re} \quad$ : "What's the difference?"

MR09 : .....(pause)

Re : "What methods did you use to find this solution?"

MR10 : "Substitution." (HSR03)

$\operatorname{Re} \quad$ : "Why are you using the substitution method instead?"

MR11 : "Because my tutor taught me like this."

In the reflective thinking component, namely elaborating, MR uses the concept of a three-variable linear equation system. MR admitted that she had encountered a similar problem by analyzing the similarities (MR08), but she could not analyze the difference between her experienced and current questions (MR09). MR uses the substitution method (HSR03) because the tutor has taught it, but on the written test, MR also uses the elimination method (HSR05).

Re : "Describe the steps in working on this problem in detail?"

MR12 : "First, we have to know what $\mathrm{x}$ is what $\mathrm{y}$ used to be, $\mathrm{x}=$ adult ticket, $\mathrm{y}=$ teen ticket, $\mathrm{z}=$ child ticket. Then we add $80000 x+50000 y+20000 z=9400000$ and $\mathrm{x}+\mathrm{y}+\mathrm{z}=170$ (HSR04). Then divide by 10000 into $8 x+5 y+2 x=940$. Then the $\mathrm{z}$ is removed so $2 \mathrm{x}+\mathrm{y}=200$."

$\operatorname{Re} \quad: \quad$ Next, what did you do after that?"

MR13 : "I am.... (confused)."

$\operatorname{Re} \quad$ :Did you check the steps for this solution earlier?"

MR14 : "No, Miss."

$\operatorname{Re} \quad: \quad$ "Try now you continue this solution!"

MR15 : "Wait a moment, Miss ..."

$\operatorname{Re} \quad:$ "Have you found the solution?"

MR16 : "Not yet, Miss, I'm confused."

$\operatorname{Re} \quad$ : "Where is your confusion?"

MR17 : "I was confused about $\mathrm{x}$ and $\mathrm{y}$, then where I substituted because there are $\mathrm{x}$, y, z above." 
$\operatorname{Re}$

: "Try to use equation 3 . There are only $\mathrm{x}$ and y."

MR18 : "Wait a moment miss.... (long) ...... I don't know."

The component of reflective thinking is contemplating. MR does not show through the written test. MR felt that there was an error in solving the questions given. Based on a written test in Figure 6, MR scribbled the results of his work. MR attempted to replace by presenting several threevariable linear equations but stopped eliminating only the $\mathrm{z}$ variable because it confused two-variable linear equations to solve them. MR does not solve until the end of solving mathematics problems (MR16). MR did not double-check the answer because she had not found a final solution. MR cannot correct the completion error, so MR cannot conclude the final result (MR18). Based on the description above, MR shows less reflective thinking in solving algebraic problems.

\section{Discussion}

Sezer (Choy \& Oo, 2012) states that reflective thinking about what awareness is known and needed. This relates to an individual's understanding of the current situation, including high school algebra problems. This study's results indicate that the three students can analyze what is known and asked ultimately. Students can retell the meaning of the algebra problem in their language. Students can explore the relationship between the known and ask verbally appropriately. Students also stated that the critical information obtained was sufficient to solve the problem. The three students have met the indicators of reflective thinking at the reacting stage from the description above.

Purnamasari et al. (2019) stated that problem-solving requires students to think reflectively. In this activity, students must be able to predict the correct answer immediately to use various strategies to identify mathematical concepts formulas that involve mathematical problems or concepts to explore problems. In this study, students with high, medium, and low mathematical abilities could analyze the mathematical concepts used to solve algebraic problems. Students with high and low mathematical abilities stated that they had encountered similar problems. Students with high mathematical abilities can analyze the similarities and differences, while low mathematical abilities only analyze the equations. Students of medium mathematical ability stated that they had never encountered a similar problem but analyzed the similarities and differences. By the opinion of Ratnasati \& Nurhidayah (2020) that students reflect on old knowledge and associate it with newly acquired knowledge to find the correct way to solve problems. The three students stated that the substitution and elimination methods were the best methods to solve linear equations' three-variable system. The three students have met the indicators of reflective thinking at the elaborating stage from the description above.

Salido \& Dasari (2019) state that the mastery of mathematical concepts is owned by subjects who have high mathematical abilities are influential in information processing and decision making in answering questions. In this study, students with high and medium mathematical abilities could explain the steps in solving algebra problems from beginning to end. Low-ability students only explain part of the completion steps because they cannot find the final result and feel confused. According Anwar \& Sofiyan (2018), the ability to think depends not only on knowledge but also on how students use existing knowledge. Students with high mathematical abilities can correct the results obtained with their respective strategies. By the opinion Sani (2016), students can re-correct the steps used to solve problems or examine the solutions obtained through reflective thinking. Students with medium mathematical abilities are not correcting their solutions, but they believe that their answers are correct. Students with low mathematical abilities are trying to improve their solutions according to the opinion Purnamasari et al. (2019) that reflective thinking allows students to improve their weaknesses. Low mathematical ability students have given up when they do not find the final result. Students with high mathematical abilities can make conclusions orally or in writing. Students with medium mathematical abilities can make conclusions oral only. Meanwhile, low mathematical abilities cannot write findings because they have not found the final result. The low category students do not meet the indicators of reflective thinking at the contemplating stage from the description above.

\section{CLOSURE}

\section{Conclusion}

Based on the study results, students with high, medium, and low mathematical abilities can retell algebraic problems in their language at the reacting stage. Students can analyze what is known and asked according to the information on the questions given. Students can explore the relationship between what is known and asked. Students state that what is known can answer the things being asked. At the elaborating stage, students with high, medium, and low mathematical abilities were able to analyze the theory used to solve algebra problems, namely a three-variable linear inequality system. Students with high and low mathematical abilities have encountered similar questions by exploring the relationship between their current problems. 
In contrast, students with medium mathematical abilities have never encountered the questions presented, but students can analyze the difference, namely the problems' shape. Students with high mathematical abilities and are currently choosing elimination and substitution methods to solve this three-variable linear equation system because it is the easiest method. Students with low mathematical abilities choose the substitution method, but the students also do the elimination method on the written test results. Students with high mathematical abilities can explain the steps in solving algebraic problems from start to finish in detail at the contemplating stage. Students with high mathematical abilities re-correct the answers obtained by substituting each equation's results and making conclusions correctly regarding written and oral algebra problems. Students with mathematical abilities are not correcting the solutions obtained and making verbal conclusions. Students with low math abilities explain the steps for the completion they get and do not correct their answers. Low mathematical ability students try to correct their mistakes but eventually give up and do not make conclusions because they have not found the final result.

\section{Suggestion}

Based on the study results, there are differences in students' reflective thinking abilities at the contemplating stage between students with high, medium, and low mathematical abilities, the teacher should choose the appropriate learning techniques and models to allow students to find their mistakes in solving mathematics problems and correct them so that their answers tend to be right. Model problem based learning is the learning model used to develop reflective thinking skills.

\section{DAFTAR PUSTAKA}

Anwar, \& Sofiyan. 2018. Teoritik Tentang Berpikir Reflektif Siswa Dalam Pengajuan Masalah Matematis. Juenal Numeracy, 5(April), 91-101.

Azis, D. M., Lukman, H. S., \& Agustiani, N. 2018. Analisis Kesalahan Siswa dalam Menyelesaikan Soal Matematika pada Materi Sistem Persamaan Linear Tiga Variabel Kelas X SMAN 1 Cisaat. Jurnal Tadris Matematika, 1(2), 193-206. https://doi.org/10.21274/jtm.2018.1.2.193-206

Booker, G. 2009. Algebraic Thinking: Generalising Number and Geometry To Express Patterns And Properties Succinctly. Algebraic Thinking: Generalising Number and Geometry to Express Patterns and Properties Succinctly, 10-21.

Cardo A.P., D., Napisah, D., Wungo, D. D., Utama, G. D.,
\& Ambarawati, M. 2020. Analisis Kesulitan Siswa dalam Mempelajari Sistem Persamaan Linear Tiga Variabel. Laplace: Jurnal Pendidikan Matematika, 3(1), 27-42. https://doi.org/10.31537/laplace.v3i1.311

Choy, C., \& Oo, P. S. 2012. Reflective Thinking and Teaching Practices: a Precursor for Incorporating Critical Thinking Into the Classroom?. Online Submission, 5(1), 167-182.

Fatmahanik, U. 2016. Realistic Mathematic Education (RME) Dalam Meningkatkan Hasil Belajar Matematika. Journal Kependidikan Dasar Islam Berbasis Sains, 1(1).

Jannah, R. N., \& Rahaju, E. B. 2018. Kemampuan Berpikir Reflektif Dalam Pemecahan Masalah Ditinjau Dari Kemampuan Matematika Siswa. Mathedu, Volume 7(No.2).

Nurman, T. A. 2008. Perangkat Pembelajaran Matematika dengan Open-Ended Problem untuk Topik Fungsi Eksponen di kelas XII IPA Sekolah Menengah Atas. Universitas Negeri Surabaya.

Purnamasari, F. E., Sujadi, I., \& Slamet, I. 2019. Effect of adversity quotient of junior high school students on reflective thinking process in mathematical problem solving. Journal of Physics: Conference Series, 1321(2), 1-6. https://doi.org/10.1088/1742$6596 / 1321 / 2 / 022128$

Puspendik. 2019. Laporan Hasil Ujian Nasional. https://hasilun.puspendik.kemdikbud.go.id/

Putri, A. S., \& Mampouw, H. L. 2018. Profil Berpikir Reflektif Siswa Dalam Menyelesaikan Soal TipeTipe Perkalian Ditinjau Dari Perbedaan Kemampuan Matematika Dan Gender. Math Didactic: Jurnal Pendidikan Matematika, 4(1), 3446. https://doi.org/10.33654/math.v4i1.81

Ratnasati, Y., \& Nurhidayah, D. A. 2020. Analisis Berpikir Reflektif Siswa Dalam Menyelesaiakan Masalah Matematika. Edupedia, 0985(10), 481124.

Salido, A., \& Dasari, D. 2019. The Analysis Of Students' Reflective Thinking Ability Viewed By Students' Mathematical Ability At Senior High School. Journal of Physics: Conference Series, 1157(2). https://doi.org/10.1088/1742-6596/1157/2/022121

Sani, B. 2016. Comparison Between Students 'Abilities in Reflective Thinking and Intuitive Thinking in Senior High School. Jurnal Pendidikan Dan Sains, 4(2), 6375.

Santrock, J. W. 2011. Educational psychology 5th edition. McGraw-Hill.

Siswono, T. Y. E. 2019. Paradigma Penelitian Pendidikan: Pengembangan Teori dan Aplikasi Pendidikan Matematika. Bandung : Remaja Rosdakarya.

Skemp, R, R. 1982. The Psychology of Learning 
Mathematics. Penguins Books.

Sugiyono. 2014. Metode Penelitian Kuantitatif, Kualitatif dan $R \& D$. Bandung : Alpabeta.

Suharna, H. 2018. Teori Berpikir Reflektif dalam Menyelesaikan Masalah Matematika. Yogyakarta: CV. Budi Utama.
Surbeck, E., Han, E. P., \& Moyer, J. 1991. Assessing Reflective Responses In Journals. Educational Leadership, 48, 25-27.

Visitasari, R., \& Siswono, T. Y. E. 2013. Kemampuan Siswa Memecahkan Masalah Berbentuk Soal Cerita Aljabar Menggunakan Tahapan Analisis Newman. Jurnal Mathedunesa, 2(2). 